\title{
BIOSYNTHESIS AND CHARACTERISTICS OF POLYHYDROXYALKANOATES. 1. POLYHYDROXYBUTYRATES OF AZOTOBACTER VINELANDII N-15
}

\author{
Ihor Semeniuk ${ }^{1}$, Tetyana Pokynbroda1, Viktoria Kochubei ${ }^{2}$, Halyna Midyana1, \\ Olena Karpenko ${ }^{1}$, Volodymyr Skorokhoda ${ }^{2, 凶}$
}

https://doi.org/10.23939/chcht14.04.463

\begin{abstract}
The biosynthesis of cellular polymers of Azotobacter vinelandii $\mathrm{N}-15$ strain using molasses as a carbon source has been optimized. The highest yield of polymer $(25.8 \%$ of cell mass) was obtained on a nutrient medium with a molasses concentration of $50 \mathrm{~g} / \mathrm{l}$. Using TL-chromatography and IR-spectroscopy the obtained product was identified as polyhydroxybutyrate (PHB), and its properties were investigated. The wetting contact angle was used to characterize the biopolymer film surface properties. According to the results of thermal and thermomechanical studies, it was found that the obtained PHB is characterized by a high thermal stability and heat resistance: the melting point is $462 \mathrm{~K}$; deep destruction and thermooxidative processes begin at the temperatures above $567 \mathrm{~K}$.
\end{abstract}

Keywords: Azotobacter, polyhydroxyalkanoates, polyhydroxybutyrate, molasses, thermomechanical analysis, complex thermal analysis.

\section{Introduction}

Plastic materials are an integral part of modern everyday life and are used for many consumer goods. They usually have a high molecular weight and do not degrade for decades after usage, which complicates their utilization and leads to negative effects on the environment. Exacerbation of problems associated with the disposal of plastic waste has led to the search and development of technology for biodegradable polymers polyhydroxyalkanoates (PHAs), which are destroyed by microorganisms in the environment under appropriate conditions such as sunlight, moisture, oxygen, etc. [1].

\footnotetext{
${ }^{1}$ Department of PhChFF InPOCC NAS of Ukraine

3a, Naukova St., 79060 Lviv, Ukraine

${ }^{2}$ Lviv Polytechnic National University,

12, Bandery St., 79013 Lviv, Ukraine

vskorohoda@yahoo.com

(c) Semeniuk I., Pokynbroda T., Kochubei V., Midyana H., Karpenko O., Skorokhoda V., 2020
}

Such polymers are produced by Rhodococcus, Pseudomonas and Azotobacter bacteria. Polyhydroxyalkonoates accumulated in bacterial cells, especially during their growth on unbalanced media, consisting of 600-35,000 monomeric units of 3-, 4-, 5- and 6hydroxyalkanoic acids which are thermoplasts and were first detected by Lemoine in Bacillus megaterium in the form of poly-3-hydroxybutyrate (PHB) [2]. Every monomer unit contains a group of side chains $\mathrm{R}$, which is usually a saturated alkyl group [3]. Depending on the chemical composition, PHAs differ in properties, but all of them are insoluble in water and resistant to hydrolysis. In addition, they are biocompatible and biodegradable, have the properties of piezoelectric materials [4]. PHAs are soluble in chloroform and other chlorine-containing solvents; glass transition temperature varies from 223 to $277 \mathrm{~K}$, melting point - from 313 to $453 \mathrm{~K}$ [5]. Assessment of the wettability, namely, measurement of the wattting contact angle, can be used to determine the surface stabilization of the modified polymer [6]. PHAs have a significant practical potential for medicine (implants, tendon and cartilage elements, sutures) [7], as drug carriers [8], etc.). In agriculture PHA are used for encapsulation of seeds and fertilizers, films for plant protection in greenhouses [9], as a packaging material [4].

However, the widespread introduction of biopolymers is limited by economic factors: the costs for separation and purification amount up to $50-80 \%$ of their total cost. PHAs are obtained in two stages: cells disintegration and polymer extraction, mainly by chlorinated hydrocarbons [11]. Moreover, the physico-chemical and thermal properties required to assess the potential in specific industries are still insufficiently described, which justifies the relevance of research in this area.

The aim of this work is to establish the optimal conditions for microbial synthesis of polyhydroxyalkonoates with various cultures, in particular, Azotobacter vinelandii N-15, their identification and study of properties to determine the practical potential. 


\section{Experimental}

\subsection{Materials}

Azotobacter vinelandii N-15 strain was purchased from the collection of State Enterprize "Enzim" (Vinnitsia, Ukraine); molasses - Enzym Private JointStock Company (Lviv, Ukraine), salts and nutrient media - Sfera Sim Ltd (Lviv, Ukraine), solvents - Sinbias Ltd. (Kyiv, Ukraine).

\subsection{Methods}

Bacteria were cultured on Ashby's medium [12] and Burk's mineral salts medium [13] with molasses as a carbon source, in Erlenmeyer flasks $(750 \mathrm{ml})$ on a rotary shaker $(220 \mathrm{rpm})$ at the temperature of $303 \pm 2 \mathrm{~K}$, pH 6.97.2 , time $48 \mathrm{~h}$. A 24 -h culture from the exponential phase, grown on Ashby's medium with molasses (3 wt \%) was used as the inoculum; cell titer was $2 \times 10^{8} \mathrm{CFU} / \mathrm{cm}^{3}$, $10 \mathrm{vol} \%$. Molasses was added in an amount of 2, 3, 4, 5 and $6 \mathrm{wt} \%$, calcium ions $\left(\mathrm{CaCO}_{3}\right.$ or $\left.\mathrm{CaSO}_{4}\right)$ in equimolar concentrations of $1,10,20$ and $30 \mathrm{mM}$, and peptone (1\%) was used as an additional source of nitrogen.

Determination of biomass. Cell biomass was determined by weight and spectrophotometric methods on KFK-2 photocolorimeter at $540 \mathrm{~nm}$ in $5 \mathrm{~mm}$ cuvettes [14].

Determination of $P H B$. To extract PHB from the biomass we used the method presented in [15] which was modified by us. The extraction was performed using chloroform with the PHB:chloroform ratio of 1:100, at the temperature of $308 \mathrm{~K}$, under stirring for $10 \mathrm{~h}$. The weight of dry polymer was determined gravimetrically.

Thermal analyzes. Thermal analysis was performed on a Q-1500D derivatograph of the Paulik-Paulik-Erdey system connected to a computer, within the temperature range of 293-1273 K with a free air access to the oven. The heating rate was $5 \mathrm{~K} / \mathrm{min}$. The averaged weight of the samples was $80 \mathrm{mg}$, the reference substance was alumina [16].

Thermomechanical studies were performed using a Heppler consistometer [17].

PHA identification. Identification of polyhydroxyalkanoates was performed by a thin-layer chromatography (TLC) on aluminum plates Merck 25 Cromatofolhas AL TLC $20 \times 20 \mathrm{~cm}$ Silicagel 60 (Germany), with ethyl acetatebenzene solvents (1:1). Visualization was carried out in an iodine chamber; the appearance of yellow-orange spots with $R_{f}=0.8$ indicated the PHB presence [18].

The infrared absorption spectra of the prepared PHB samples were recorded by a Thermo scientific Nicolet iZ10 interference Fourier spectrophotometer (USA) using diamond windows. The IR spectra were recorded in the wave numbers range from 4000 to $525 \mathrm{~cm}^{-1}$.
Measurements of the wetting contact angle (WCA). The formation of polymer films to determine the WCA was performed by pouring $2 \%$ solutions of PHB in Petri dishes. The films were dried in the air till the constant weight.

The surface properties of polymer films were characterized by the value of WCA, which was measured by a Drop Shape Analysis System - DSA100 (KRÜSS, GmbH, Germany) according to the procedure described in [19].

\section{Results and Discussion}

Polyhydroxybutyrate (PHB) is a polymer of 3-hydroxybutane acid. It contains the ester bond which is formed via the reaction of carboxy group of one monomer and hydroxy group of another monomer.<smiles>CC(O)CC(=O)O</smiles>

Polyhydroxybutyrate structure

\subsection{Choice of the Nutrient Medium Rational Composition for the PHB Synthesis}

The choice of economically viable raw materials for the cultivation of producers is one of the important factors of modern biotechnology. In this study to obtain PHB of Azotobacter vinelandii N-15 strain we used molasses as a carbon source. Molasses is a by-product of sugar production from beets, which apart from sucrose contains nitrogen-containing compounds, nitrogen-free carboxylic acids, and inorganic salts. Such nutrients can stimulate the growth of microorganisms and the synthesis of the resulting product. The effect of molasses concentration in the nutrient medium on the yield of biomass and PHB is represented in Fig. 1.

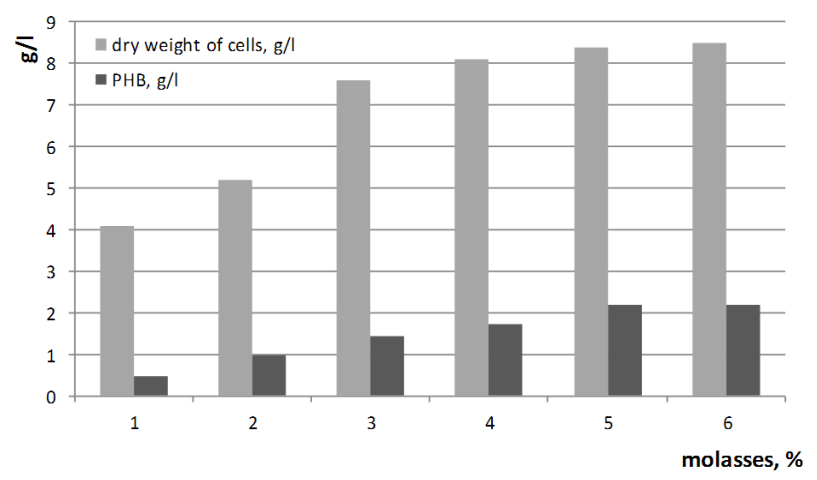

Fig. 1. Yields of biomass and PHB molasses concentration in the nutrient medium during Azotobacter vinelandii $\mathrm{N}-15$ cultivation 
According to the experimental data, at $303 \mathrm{~K}$ and $\mathrm{pH} 7.5$ the highest yield of the resulting PHB product $(25.8 \%)$ can be obtained at molasses concentrations of $50-60 \mathrm{~g} / \mathrm{l}$ (Fig. 1).

\subsection{Identification of Cellular Biopolymer}

The nature of the obtained polymer was confirmed by a thin-layer chromatography (TLC) [18]. Yellowish spots characteristic of PHA were registered on the plate visualized in the iodine chamber. The retention factor $R f=0.8$ confirmed that the sample under study is PHB.

IR analysis of the samples shows a wide band at $3600-3100 \mathrm{~cm}^{-1}$ (Fig. 2), which corresponds to the stretching vibrations of both alcohol and acid end groups $(-\mathrm{OH})$. The band at $1226 \mathrm{~cm}^{-1}$ corresponding to the stretching asymmetric vibrations of $\mathrm{C}-\mathrm{O}-\mathrm{C}$ group $\left(v_{a s(\mathrm{C}-\mathrm{O}-\mathrm{C})}\right)$, confirms the presence of PHB functional bonds. The band at $1712 \mathrm{~cm}^{-1}$ corresponds to the stretching vibrations of the carbonyl group $\left(v_{\mathrm{C}=0}\right)$. The bands at 2976 and $2933 \mathrm{~cm}^{-1}$ correspond to the asymmetric and symmetric stretching vibrations of the $\mathrm{CH}_{2}$ group, respectively; the absorption bands at 2990 and $2860 \mathrm{~cm}^{-1}-$ to the asymmetric and symmetric stretching vibrations of the $\mathrm{CH}_{3}$ group, respectively; the bands at 1452 and $1300 \mathrm{~cm}^{-1}$ - to the deformational vibrations of $\mathrm{CH}_{3}$ and $\mathrm{CH}_{2}$ groups, respectively. The obtained results are in agreement with literature data $[20,21]$.

\subsection{Wetting Contact Angle of PHB}

The value of WCA is one of the characteristics of the polymer surface stability. The balance between the surface hydrophobicity and hydrophilicity itself is one of the main characteristics related to the biocompatibility of the surface, which is an important property of polymer to be used in medicine. The greater the hydrophilicity of the polymer, the better its biocompatibility [19]. The measured wetting contact angle was $70.5^{\circ}$, which provides a good biocompatibility of PHB and the prospect of its use in biomedicine.

\subsection{Thermal Analyzes}

Thermal stability and heat resistance are the important characteristics of biopolymers. The results of complex thermogravimetric, differential thermogravimetric and differential thermal analysis of the biopolymer under study are shown in Fig. 3.

At the first stage of thermolysis, in the temperature range of $433-478 \mathrm{~K}$, the PHB sample melts. This process is accompanied by the appearance of a clear endothermic effect on the DTA curve with a maximum at the temperature of $450 \mathrm{~K}$ without mass loss.

At the second stage of thermolysis in the temperature range of $478-567 \mathrm{~K}$, the thermooxidative and destructive processes begin. They are accompanied by a loss of sample mass $(13.7 \%)$ and the appearance of an exothermic effect on the DTA curve, with a maximum at the temperature of $539 \mathrm{~K}$.

In the third stage of thermolysis, in the temperature range of $567-611 \mathrm{~K}$, the sample undergoes deep destructive processes, which are accompanied by the intense mass loss of the sample $(84.0 \%)$ and the appearance of a deep endothermic effect on the DTA curve with a maximum at $595 \mathrm{~K}$, and a clear extremum on the DTG curve, with a maximum at $582 \mathrm{~K}$.

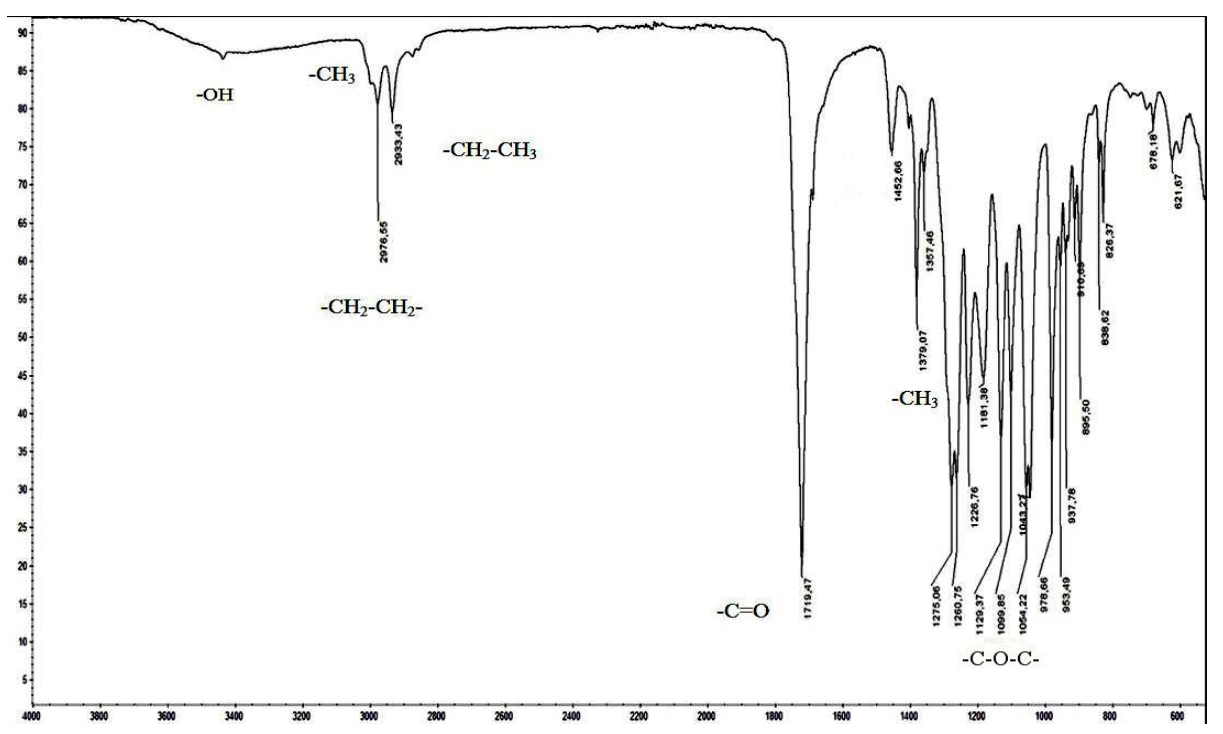

Fig. 2. IR spectrum of cellular polymer PHB of Azotobacter vinelandii $\mathrm{N}-15$ 
In the temperature range of $611-763 \mathrm{~K}$, at the fourth stage of thermolysis, the combustion of destruction residues takes place. This process corresponds to the sample mass loss of $1.5 \%$ and the appearance of an exothermic effect on the DTA curve, with a maximum at $656 \mathrm{~K}$. The process is finished with the combustion of the pyrolytic residue within $763-1073 \mathrm{~K}$. This process corresponds to the mass loss of $0.8 \%$ and the appearance of an exothermic effect on the DTA curve, with a maximum at $858 \mathrm{~K}$.

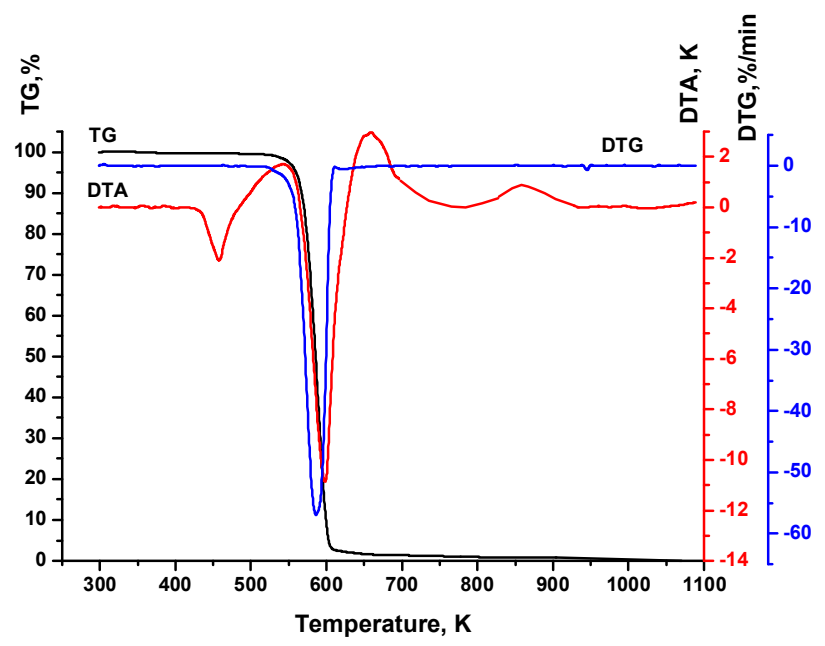

Fig. 3. Thermogram of polyhydroxybutyrate of Azotobacter vinelandii N-15

Thus, according to the thermal analysis, the PHB sample is characterized by a high thermal stability and heat resistance. Its melting point is high $(450 \mathrm{~K})$, the maximum is observed at $462 \mathrm{~K}$; the beginning of intensive

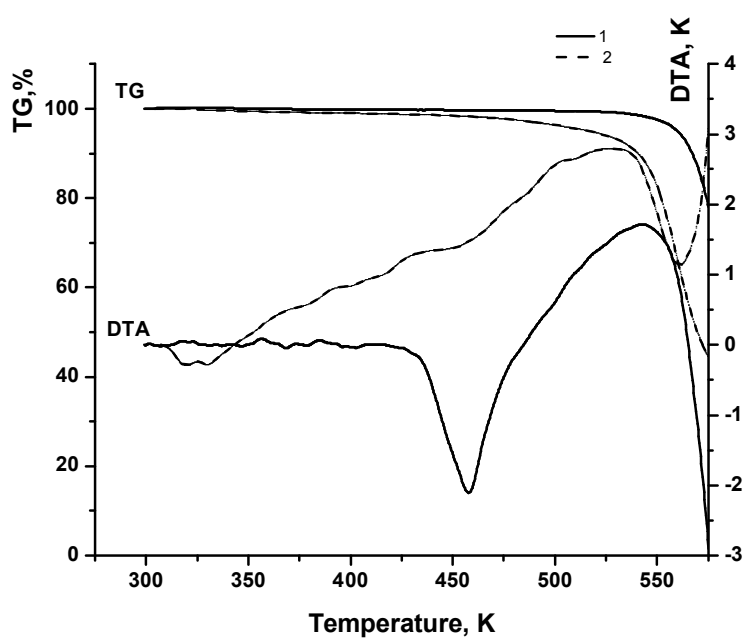

Fig. 4. Comparison of TG and DTA for PHB of Azotobacter vinelandii N-15 strain (1) and mcl-PHA of Pseudomonas sp. PS-17 strain (2) mass loss of the sample caused by deep destructive and thermooxidative processes is shifted to the region of high temperatures $(317 \mathrm{~K})$.

Previously [15] we have synthesized and investigated the cellular biopolymer of the Pseudomonas sp. PS-17 strain - polyhydroxyalkanoate with a medium length $\mathrm{C}_{5}-\mathrm{C}_{10}$ chain - (mcl-PHA) [15]. The results of thermal analyzes of biopolymers mcl-PHA and PHB show that they significantly differ in the values of melting and destruction temperatures (Fig. 4).

As can be seen from the DTA results, the mcl-PHA sample melts at the temperature of $319 \mathrm{~K}$. The intense mass loss, which corresponds to deep destructive and thermooxidative processes, begins at $499 \mathrm{~K}$. The PHB sample (unlike PNA) is characterized by a greater thermal stability and heat resistance (melting point is $462 \mathrm{~K} v s$. $309 \mathrm{~K}$ ), and the destruction begins at the temperatures above $567 \mathrm{~K}$.

The DTA results are in a good agreement with the performed thermomechanical studies, which were aimed to establish the regularities of polymer deformation under the simultaneous action of mechanical and thermal fields. The mcl-PHA of Pseudomonas sp. PS-17 strain was investigated and PHB of Azotobacter vinelandii N-15 strain was taken for the comparison.

The thermomechanical curve of both biopolymers clearly identifies the steep ascending region typical of crystalline polymers, which corresponds to the structural transition of the polymer from the vitreous to the viscous state. This is due to the mobility deceleration of the polymer matrix kinetic segments under the action of temperature [18]. Moreover, analyzing the nature of the curves, we can conclude that the polymer PHB of Azotobacter vinelandii $\mathrm{N}-15$ strain is highly crystalline.

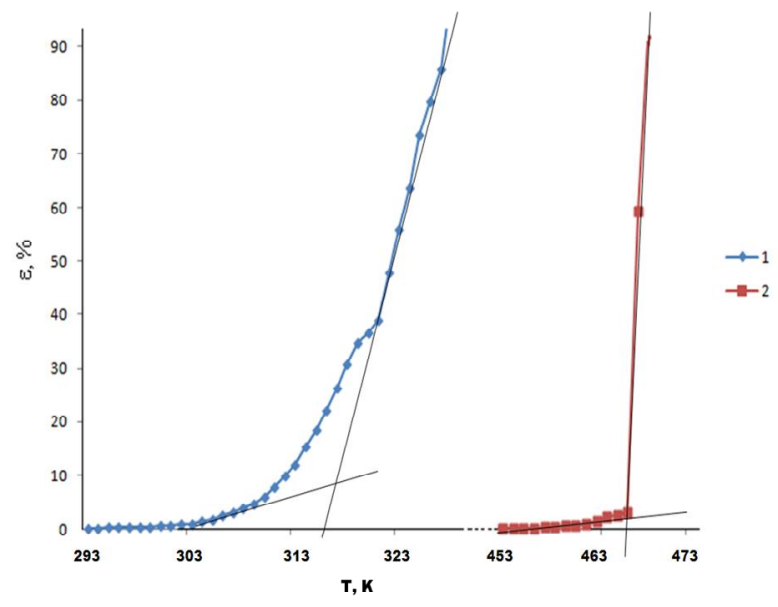

Fig. 5. Thermomechanical curves for mcl-PHA of Pseudomonas sp. PS-17 strain (1) and PHB of Azotobacter vinelandii $\mathrm{N}-15$ strain (2) 
It can also be predicted that the maximum operating temperature of mcl-PHA obtained via the Pseudomonas sp.PS-17 strain biosynthesis is about $313 \mathrm{~K}$. The relatively low heat resistance implies the limited use of such polymers, in particular, they can be used as packaging materials for medicines and food products, containers for cold food and beverages. The heat resistance of the PHB strain of Azotobacter vinelandii N15 (Fig. 5, curve 2) is much higher - almost $463 \mathrm{~K}$. This significantly expands the possibilities of using such polymers, in particular, as materials for medical and pharmaceutical purposes, which can withstand sterilication in an autoclave, osteoplastic materials, products for bone replacement, etc.

Thus, biodegradable cellular polymers with different thermophysical properties were obtained by a microbial synthesis. The obtained results are important for scientifically substantiated application of new products of biotechnology in the corresponding spheres of human life.

\section{Conclusions}

The efficiency of molasses (a by-product of sugar production) as a carbon source for the biosynthesis of cellular polymer of Azotobacter vinelandii $\mathrm{N}-15$ strain has been proved. The maximum polymer yield was obtained on a medium with molasses $(50 \mathrm{~g} / \mathrm{l})$ at the temperature of $303 \mathrm{~K}, \mathrm{pH}=7.5$, for $48 \mathrm{~h}$; the biopolymer yield was $25.8 \%$ per cell weight.

The obtained product was identified as polyhydroxybutyrate by means of TLC and IR spectroscopy. The wetting contact angle of the biopolymer film surface was found to be 70.5, indicating its hydrophilic properties.

According to the results of thermal and thermomechanical studies, it was found that the obtained biopolymer is characterized by the high thermal stability and heat resistance, the melting point is $462 \mathrm{~K}$, and the destruction begins at the temperatures above $567 \mathrm{~K}$.

\section{References}

[1] Abe H., Doi Y.: Molecular and material design of biodegradable poly(hydroxyl-alkonate)s' [in:] Doi Y., Steinbuchel A. (Eds.), Biopolymers 3b, Polyesters II. Wiley-VCH, Weinheim 2002,105132. https://doi.org/10.1002/3527600035.bpol3b05

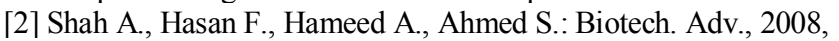
26, 246. https://doi.org/10.1016/j.biotechadv.2007.12.005

[3] Khanna S.; Srivastava A.: Proc. Biochem., 2005, 40, 607. https://doi.org/10.1016/j.procbio.2004.01.053

[4] Bugnicourt E., Cinelli P., Lazzeri A., Alvarez V.: Express Polym. Lett., 2014, 8, 791.

https://doi.org/10.3144/expresspolymlett.2014.82

[5] Padermshoke A., Katsumoto Y., Sato H. et al.: Spectrochim.

Acta. A, 2005, 61, 541. https://doi.org/10.1016/j.saa.2004.05.004
[6] Slepickova Kasalkova N., Slepicka P., Kolska Z., Svorcik V.: Wettability and other Surface Properties of Modifies Polymers. InTech 2015. https://doi.org/10.5772/60824

[7] Chen G., Wu Q.: Biomaterials, 2005, 26, 6565.

https://doi.org/10.1016/j.biomaterials.2005.04.036

[8] Shishatskaya E., Voinova O., Goreva A. et al.: J. Mater. Sci., 2008, 19, 2493. https://doi.org/10.1007/s 10856-007-3345-6

[9] Saini S., Rao P., Patil Y.: Procedia Soc. Behav. Sci., 2012, 37, 407. https://doi.org/10.1016/j.sbspro.2012.03.306

[10] Halami P.: World J. Microbiol. Biotechnol., 2008, 24, 805. https://doi.org/10.1007/s11274-007-9543-z

[11] Kunasundari B., Sudesh K.: Express Polym. Lett., 2011, 5, 620. https://doi.org/10.3144/expresspolymlett.2011.60

[12] Tejera N., Lluch C., Martínez-Toledo M., González-López J.:

Plant Soil, 2005, 270, 223. https://doi.org/10.1007/s11104-004-1522-7

[13] Page W.: FEMS Microbiol. Lett., 1992, 103, 149.

https://doi.org/10.1016/0378-1097(92)90304-7

[14] Gerhardt P., Murray R., Wood W., Krieg N.: Methods for General and Molecular Bacteriology. Am. Soc. for Microbiol., Washington 1994. https://doi.org/10.1002/food.19960400226

[15] Semeniuk I., Kochubei V., Skorokhoda V. et al.: Chem. Chem.

Technol., 2020, 14, 26. https://doi.org/10.23939/chcht14.01.026.

[16] Semeniuk I., Kocubei V., Karpenko O. et al.: Voprosy Khimii i Khimicheskoi Tekhnologii, 2019, 4, 150.

https://doi.org/10.32434/0321-4095-2019-125-4-150-156

[17] Telteibaum B.: Termomechancheskiy Analiz Polimerov.

Nauka, Moskva 1979.

[18] Panda B., Sharma L., Singh A., Mallick N.: Indian J.

Biotechnol., 2008; 7, 230.

[19]. Bonartsev A., Yakovlev S., Zharkova I. et al.: BMC Biochem., 2013, 14, 12. https://doi.org/10.1186/1471-2091-14-12

[20] Nisha J., Mudaliar N., Senthilkumar P., Samrot A.: African J. Microbiol. Res., 2012, 6, 3623.

https://doi.org/10.5897/AJMR11.1509

[21] Mohapatra S., Samantaray D., Samantaray S.: Indian J. Sci.

Technol., 2015, 8, 1. https://doi.org/10.17485/ijst/2015/v8iS7/64027

Received: March 04, 2019 / Revised: March 17, 2019 / Accepted: June 11, 2019

\section{БІОСИНТЕЗ ТА ХАРАКТЕРИСТИКИ ПОЛІГЦДРОКСІАЛКАНОАТІВ. 1. ПОЛІГІДРОКСИБУТИРАТИ КУЛЬТУРИ AZOTOBACTER VINELANDII N-15}

Анотація. Здійснено оптимізацію біосинтезу клітинних полімерів культури Azotobacter vinelandii N-15 з використанням меляси як джерела вуглецю. Найвищий вихід полімеру $(25,8 \%$ від клітинної маси) був отриманий на поживному середовищі 3 концентрацією меляси 50 г/л. За допомогою тонкошарової хроматографії та ІЧ-спектроскопії отриманий продукт був ідентифікований як полігідроксибутират, його властивості були досліджені. Поверхневі властивості полімерної плівки охарактеризовано значенням крайового кута змочування. За результатами термічних і термомеханічних досліджень було встановлено, що отриманий полігідросибутират характеризується високою термостійкістю і теплостійкістю: температура плавлення становить 462 К, глибока деструкція і термоокисні процеси відбувається за температур, вищих $567 \mathrm{~K}$.

Ключові слова: Azotobacter, полігідроксіалканоати, полігідросибутират, меляса, термомеханічний аналіз, комплексний термічний аналіз. 